\title{
You Can't Drag Them Away: An Economic Analysis of the Wild Horse and Burro Program
}

\author{
Vanessa Elizondo, Timothy Fitzgerald, and Randal R. Rucker
}

\begin{abstract}
Since 1971 wild horses and burros living on federal land have been legally protected, limiting removal from the range and stipulating restrictive conditions for transfer to private ownership. Periodic gathers prevent overpopulation, though we find both political and biological influences on the probability and size of gathers. Attempts to convey removed horses to private owners are often unsuccessful because of the relatively low quality of some animals and contractual restrictions. We consider alternative policy regimes promoting the transfer of additional animals; such reforms could have reduced program costs by as much as $\$ 452$ million over the past twenty-five years.
\end{abstract}

Key words: natural resources policy, public lands, wild horses and burros

\section{Introduction}

The policies that regulate the management of wild horses and burros in the western United States have received increasing media attention in recent years. ${ }^{1}$ A primary reason for the growing attention is the rapidly rising treasury costs associated with the supervision of these animals by the Bureau of Land Management (BLM). As of 2014, the BLM was holding about 50,000 unadopted wild horses in short-term or long-term pastures (U.S. Department of Interior, Bureau of Land Management, 2014a). The estimated population of free-roaming wild horses and burros under the authority of the BLM was almost 50,000 in March 2014, which exceeds the legislatively allowed level by more than 22,500 (U.S. Department of Interior, Bureau of Land Management, 2015). Under current legislative mandates, these "excess" animals will have to be removed from the range in the near future. Some of these animals will be adopted or sold to private buyers, but under current policies, many more will add to the BLM's annual pasturage bill in both temporary and permanent facilities.

A $2008 \mathrm{GAO}$ report found that the average daily costs of short- and long-term holding per head were $\$ 5.08$ and $\$ 1.27$. Horses captured by the BLM can be transferred to new owners through a number of channels. Those horses not transferred through any of the available avenues are often held in short-term facilities, sometimes for two or three years, and are then placed in a long-term pasture

Vanessa Elizondo is a member of the Facultad de Ciencias Jurídicas y Sociales at the Universidad de Concepción, Chile. Timothy Fitzgerald is an assistant professor and Randal R. Rucker is a professor at Montana State University.

The authors wish to acknowledge the invaluable assistance of Bea Wade with the Nevada BLM. Staff at BLM too numerous to mention individually were also helpful. Comments from participants at the 2011 CAES-WAEA Joint Annual Meeting, 13th Colorado Environmental and Resource Economics Workshop, and two reviewers are appreciated. The authors would like to thank David Buschena for his thoughts and feedback early in this project, the Montana Agricultural Experiment Station for support, and The Rolling Stones for their continuing inspiration.

Review coordinated by Christopher S. McIntosh.

1 As an example of high-profile media coverage, see The Economist (2011). 
for twenty to thirty years. The holding costs alone for one of these horses are almost $\$ 16,000 .^{2}$ As a result of increases in animals in long-term holding from 9,800 in 2001 to almost 50,000 in 2014, this component of the BLM's costs has also increased dramatically—from \$7 million in 2000 to $\$ 46$ million in 2013 (General Accountability Office, 2008; U.S. Department of Interior, Bureau of Land Management, 2014a). Appropriations for the Wild Horse and Burro (WH\&B) program in FY2013 were $\$ 71.8$ million, suggesting that holding costs represented $64 \%$ of total expenditures, as compared with $35 \%$ in 2000.

Suppose that the costs of the WH\&B program continued to increase at the same rate as they increased between 2000 and 2013; the nominal costs of the program would reach $\$ 250$ million midway through 2020. Such costs are not politically acceptable, and the BLM is currently in the process of developing program modifications to control them. ${ }^{3}$ Taxpayers are not the only interest group with a voice in policy discussions. Livestock producers using BLM grazing allotments have a vested interest and bear opportunity costs associated with wild horse and burro management. Wild horse advocacy groups are an important force that has gained prominence in recent years. Other environmental groups have an interest in the program, particularly with respect to tradeoffs with other species such as the endangered desert tortoise and various game animals.

Despite the growing media attention being focused on wild horses and burros-and increasing criticism of the BLM's administration of the WH\&B program-no formal analysis of the economic impacts of the program has been conducted, either by the BLM or by its detractors. A few studies examine the effectiveness and costs of fertility control in wild horse populations (Gross, 2000; Hobbs, Bowden, and Baker, 2000; Bartholow, 2007), and Huffaker, Wilen, and Gardner (1990) investigates the dynamics of the bioeconomic tradeoff between livestock and wild horses. ${ }^{4}$ Most recently, in response to a request from Congress, the BLM asked the National Academy of Science to study the current wild horse polity. The resulting report focuses on the resource demands of 15$20 \%$ annual growth in horse populations and recommends wider use of contraceptives to help reduce growth rates and pressures created by an oversupply of horses (National Research Council, 2013).

\section{History of the Wild Horse and Burro Program}

The wild horses and burros managed by the BLM and Forest Service are descendants of domestic stock that were released or escaped onto the open range. ${ }^{5}$ Over the years these animals have sometimes been viewed as potentially valuable breeding stock and at other times as pests consuming valuable forage. Mustangers served both views by capturing wild horses. The first significant attempt to curtail the widespread capture of wild horses for slaughter was in 1959, when legislation prohibited the use of motorized vehicles for capturing and killing wild horses on public lands. Although the lobbying efforts for this act brought the condition and treatment of wild horses and burros to the general public's attention, the legislation failed to establish a clear legal status for the animals and did not provide for enforcement of the provisions of the act.

\footnotetext{
${ }^{2}$ For a wild horse that lives for twenty-five years after being captured, with the first three years spent in short-term holding facilities, the calculation is $\$ 5.08 \times 365 \times 3+\$ 1.27 \times 365 \times 22=\$ 15,760.70$. Assuming these costs increase at the rate used to discount future dollars, this amount can be viewed as the present value of discounted future costs. Gather, removal, and miscellaneous costs for unadopted animals are close to \$2,000 (U.S. Department of Interior, Bureau of Land Management, $2014 b$ ). Our estimates of holding costs are substantially less than other estimates as high as $\$ 45,000$ (\$2014), with the difference due to the difficulty for the BLM in negotiating adequate long-term holding arrangements at current average cost.

3 It appears, however, that the number of "excess" horses on the range has substantially increased recently, which may indicate that cost increases are simply being delayed.

${ }^{4}$ Additional studies of food and habitat relations between wild horses, domestic livestock, and wildlife herbivores have been carried out by Hubbard and Hansen (1976); Olsen and Hansen (1977); Hansen, Clark, and Lawhorn (1977); Miller (1983); Krysl et al. (1984); and McInnis and Vavra (1987).

5 See Elizondo (2011) for additional background information on wild horses and burros in North America and also for additional details on the legislative history of the WH\&B program. Principal sources for background information on the former include McKnight (1959), Thomas (1979), and Wyman (1945). We acknowledge the distinction between "wild" and "feral" animals, where the latter have domestic ancestors and now live in the wild. Given the conventions in the industry and the literature, however, we refer to the populations as wild horses and burros.
} 
Following continued lobbying efforts by wild horse advocates, Congress unanimously enacted the Wild Free-Roaming Horses and Burros Act in 1971. The WH\&B Act directed the Secretaries of the Interior and Agriculture to protect and manage wild free-roaming horses and burros to achieve and maintain a "thriving natural ecological balance" on the public lands. To accomplish this legislative mandate, the BLM identifies herd areas-areas of the public lands recognized as habitat used by wild horses and burros in 1971 and before - and herd management areas (HMAs) defined as herd areas within which wild horses and burros can be maintained over the long term.

Problems soon arose with the management of wild horse and burro populations. Wild horse and burro numbers rapidly increased under the new protections, and rangelands deteriorated to the point where the animals were dying of starvation. In response, the BLM began to cut back on the number of livestock that could be grazed and started removing excess wild horses and burros. To dispose of these animals, the BLM came to rely on adoption by private individuals. In 1973, the first animals (twenty-three horses from the Pryor Mountain Wild Horse Range along the Montana-Wyoming border) were adopted by private owners. By 1976, favorable public response to this approach led the BLM to institute a nationwide adoption program, which is now the main mechanism used to transfer horses from government control.

With the enactment of the Public Rangeland Improvement Act (PRIA) in October 1978, the Secretaries of the Interior and Agriculture were directed to determine an Appropriate Management Level (AML) for each HMA. The purpose of an AML is to establish a population range within which wild horses and burros can be successfully managed over the long term. The BLM determines the population level set as an AML based on (1) the number of acres within the resource planning area allocated for wild horse and burro management and (2) the proportion of the available forage assigned to wild horses and burros rather than to other species, such as livestock and wildlife. ${ }^{6}$ Additional factors considered in the determination of AMLs are census inventories of wild horses and burros, water availability, herd health, and unique local conditions. ${ }^{7}$ Using AMLs to manage wild horse and burro populations without considering management costs or value of the animals suggests that the BLM is using an ecological, as opposed to a bioeconomic, decision rule.

The main management tool the BLM uses to achieve an AML is to conduct "gathers" to remove excess animals from the range. The BLM employs private contractors who guide the animals into temporary on-site corrals. Once the animals are collected (usually using helicopters), the BLM selects the animals to be removed from the HMA based on age and expected adoptability as well as the sex ratio and age structure of the herd. ${ }^{8}$ Animals not selected are released and returned to the open range. After being removed, wild horses and burros are taken to short-term holding facilities, where "they receive vaccinations and other treatment prior to either being adopted, sold, or sent to long-term holding facilities" where they live out the remainder of their lives-often twenty to thirty years (General Accountability Office, 2008, p. 19).

The Adopt-a-Horse program was created in the 1978 PRIA. This program, which remains in effect today, allows individuals to obtain title to up to four horses in a twelve-month period for a minimum adoption fee of $\$ 125$ each. Most of the animals transferred under this program have been adopted through competitive auctions since $1997 .{ }^{9}$ A wild horse or burro belongs to the federal

\footnotetext{
${ }^{6}$ Available forage is determined based on climatic data, utilization data, actual use data, and trend data. Some of the controversy surrounding wild horses and burros is related to how AMLs are set and how current populations are estimated. National Research Council (2013) addresses these scientific issues in detail.

7 See General Accountability Office (2008) for details.

8 This policy of selective removal was initiated by the BLM in 1992 and applies only to wild horses. The current selective removal criteria mandate the removal of first wild horses four years old and younger, then wild horses eleven to nineteen years of age, and finally wild horses five to ten years old. In addition, the BLM considers alternatives for slowing population growth rates and extending the gather cycle, examples of which include fertility control, adjusting the sex ratio of the herd in favor of males, and management of selected HMAs for non-reproducing wild horses, which is accomplished by gelding stallions in the herd. For more detail, see U.S. Department of Interior, Bureau of Land Management (Various Years).

${ }^{9}$ On March 8, 1997, the BLM changed its regulations to offer wild horses and burros for adoption using a competitive bid process. See Elizondo (2011) and U.S. Department of Interior, Bureau of Land Management (1998) for details on alternative methods occasionally used, as well as circumstances under which animals can be adopted for less than \$125.
} 
government until the BLM issues a certificate of title. Adoption is probationary for one year. After one year and verification of proper care, the BLM issues the certificate of title to the adopter, at which point the animal becomes the adopter's private property and loses its status as a wild free-roaming horse or burro. The BLM's efforts to prevent commercial use or slaughter of formerly free-roaming wild horses and burros become more costly as time passes after the transfer of title.

The most recent amendment to the WH\&B Act, which was passed in December 2004, allows the BLM to sell excess wild horses and burros if the animals are more than ten years of age or have been offered unsuccessfully for adoption at least three times. Congress placed no limitations or restrictions on who can purchase these animals, though resale for slaughter is prohibited in the bill of sale. Under this authority, prices are negotiated on a case-by-case basis. A buyer can purchase any number of these animals, and they become the buyer's private property immediately upon purchase, so provisions to prevent sale for slaughter are more costly to enforce than in the adoption case, when title is withheld for one year. Under this new sale authority, approximately 8,400 wild horses became eligible for sale as of March 2004 (U.S. Department of Interior, Bureau of Land Management, 2005). Between 2005 and 2010, BLM data indicate that over 4,100 horses were sold under this provision at an average real price of $\$ 17$ per head.

\section{Political Economy Analysis}

Wild horse and burro management is a sensitive issue, subject to substantial lobbying and political pressure. Our objectives for this component of our analysis are to identify the relevant interest groups, to determine their positions on various issues, and to examine available data to ascertain whether the WH\&B management decisions made by the BLM are consistent with the constituent groups' interests. The particular management decisions we examine empirically are the timing of gathers (to control populations) and how many animals are gathered and removed from the range. These decisions effectively determine the supply of wild horses for the Adopt-A-Horse program and its surrogates.

We identify two primary interest groups: livestock producers (in particular, those holding permits to graze on public lands) and wild horse and burro advocacy groups. ${ }^{10}$ These two groups have conflicting interests regarding various aspects of the management of wild horse and burro populations. Since shortly after the WH\&B program was implemented, both of these interest groups have generated substantial judicial and administrative activity that has shaped the managerial tools employed by the BLM in administering the program. ${ }^{11}$

We make two intuitive predictions regarding the influence of these groups. The first prediction concerns the impact of livestock groups. Many livestock producers have BLM grazing permits (or allotments) for land that is also designated as part of HMAs. These permits allow livestock producers to graze contractually specified numbers of cattle on designated BLM acreage for a stipulated fee. Insofar as the population of wild horses in a particular HMA is within the limits established by the AML, remaining pasture is available for livestock. If the population of horses exceeds the AML, then pasture for livestock becomes more scarce and livestock producers have an incentive to lobby the BLM to gather the excess horses.

For a given HMA, the more livestock producers there are with leases that overlap the HMA, the more producers there are who have incentives to lobby the BLM to gather excess horses. Bastian et al. (1997) estimate the opportunity costs of foregone feed for livestock and wildlife to be $\$ 1,900$ per wild horse in excess of the AML. We predict that these greater lobbying efforts will increase the likelihood of a gather in any given year, especially when there are wild horses and burros in

10 A primary source for this identification is testimony from the congressional subcommittee hearings related to wild horses and burros. See Elizondo (2011) for a detailed discussion of these hearings. We also identify wildlife managers and advocates as an interest group but conclude that the role they have played vis-à-vis the WH\&B program is minor relative to livestock producers and to wild horse and burro advocacy groups.

${ }^{11}$ For a more complete and detailed analysis of the judicial and administrative activity generated around the WH\&B program, see Iraola (2005) and Buckley and Buckley (1982, 1983). 
excess of the AML. We also predict that such increased lobbying will increase the number of horses removed when a gather is conducted.

With respect to the wild horse advocacy groups, we predict that increased lobbying efforts on their part will have an influence. These groups typically lobby to dispute the BLM's estimates of wild horse populations and to delay or prevent gathers. Lobbying efforts, which may take the form of lawsuits, lobbying at subcommittee hearings, administrative suits, or drawing attention from the media, are intended to help protect and sustain populations of wild horses and burros. We predict that successful lobbying will decrease the likelihood of gathers in any given year and will decrease the number of animals removed when a gather is conducted.

\section{Data and Empirical Analysis}

The data for the political economy analysis were primarily obtained from the BLM. We compiled annual information on the BLM's estimates of wild horse and burro populations, AMLs, and gathers by HMA during the years 2004-2008. Data were also collected on the number of BLM grazing permits that overlap each of the 195 HMAs. During the summer and fall of 2010, when these data were collected, the BLM's Geocommunicator contained information on grazing leases as of 2006. The areas covered by BLM grazing leases and HMAs do change, but not frequently. Accordingly, we use the 2006 data on the location of grazing permits and link them to data on gathers.

Unfortunately, we found little concrete data on membership in wild horse advocacy organizations, so we collected annual state-level data on the number of members of the Sierra Club for the years spanned by our analysis. From these, we calculate the number of Sierra Club members per thousand population as a proxy for the relative level of influence of environmentalists. Finally, data on the number of lawsuits intended to halt gathers were collected from the LexisNexis Academic database. Only lawsuits with judgments appear in this database, so the three lawsuits we identify during our time period may underestimate the actual number of legal actions filed. ${ }^{12}$

To test whether political pressures affect decisions to conduct gathers of excess animals, the following two specifications are employed:

$$
\text { Gather }_{i t}=f\left(\text { Excess Animals }_{i t}, \text { Overlap Number }_{i},\right.
$$

$$
\text { Sierra Club Membership } \left.{ }_{i t}, \text { Lawsuits }_{i t}\right)+\varepsilon_{i t}
$$

and

$$
\text { Animals Removed }_{i t}=f\left(\text { Excess Animals }_{i t}, \text { Overlap Number }_{i},\right.
$$

$$
\text { Sierra Club Membership } \left.{ }_{i t}, \text { Lawsuits }_{i t}\right)+\mu_{i t},
$$

where $i=1 \ldots 195$ identifies HMAs and $t=2004-2008$ indicates the year.

The dependent variable in equation (1), Gather ${ }_{i t}$, is a binary variable equal to one if a gather was conducted in HMA $i$ during year $t$ and zero otherwise. We assign the dependent variable in

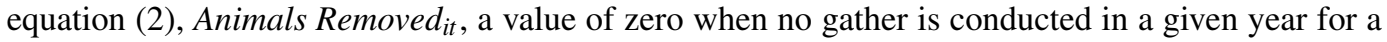
particular HMA. When a gather is conducted, the value is the actual number of animals removed.

The variable Excess Animals Et $_{i t}$ is the difference between the estimated population of wild horses and burros and the AML for HMA $i$ in year $t$. For observations where the estimated population is less than the AML, we assign Excess Animals a value of zero. The WH\&B Act states that AMLs are to

\footnotetext{
12 The first lawsuit we identify was filed by the Cloud Foundation in 2006 and involved the Pryor Mountain Wild Horse Range HMA in Montana. This lawsuit objected to the BLM's finding of an overpopulation of wild horses in the HMA, the BLM's decision to use the immunocontraceptive agent porcine zona pellucida (PZP) for fertility control on wild horses, and the finding of no significant impact in its use. The second lawsuit was filed by America's Wild Horse Advocates in late 2006 to stop a plan to gather wild horses and burros from three Nevada HMAs—Johnnie, Red Rock, and Wheeler Pass. The third lawsuit was filed by several pro-WH\&B groups in 2008 involving the Piceance-East Douglas HMA in Colorado. The lawsuit sought the implementation of a restraining order to prevent the removal of wild horses from this HMA.
} 
Table 1. Summary Statistics for HMA-Years: Political Economy Analysis

\begin{tabular}{lcccc}
\hline Variable & Mean & SD & Min & Max \\
\hline Gather & 0.219 & 0.414 & 0 & 1 \\
Animals Removed & 39 & 122.7 & 0 & 1235 \\
Excess Animals & 52 & 103.1 & 0 & 808 \\
Overlapping Allotments & 9.390 & 9.039 & 0 & 62 \\
Sierra Club Members/1000 & 2.465 & 1.321 & 1.345 & 5.876 \\
Lawsuit & 0.005 & 0.071 & 0 & 1 \\
Lagged Lawsuit & 0.004 & 0.064 & 0 & 1 \\
Excess Animals 0-50 & 0.778 & 0.415 & 0 & 1 \\
Excess Animals 51-150 & 0.141 & 0.348 & 0 & 1 \\
Excess Animals 151-300 & 0.058 & 0.235 & 0 & 1 \\
Excess Animals $>300$ & 0.023 & 0.149 & 0 & 1 \\
\hline
\end{tabular}

Notes: 975 observations of HMA-years across 195 different HMAs. Over that time period, 214 gathers took place. Lawsuits counted are those that reached a judgment between 2004 and 2008. The Sierra Club membership variable is calculated as the number of Sierra Club members divided by the population measured in thousands of people.

be achieved by the removal or destruction of excess animals (i.e., wild horse and burro populations in excess of the AML). Insofar as the BLM follows its mandate in managing wild horses and burros, when the number of excess animals on a given HMA increases, we predict that both the likelihood of a gather and the number of animals removed will increase.

The variable Overlap Number ${ }_{i}$ measures the total number of grazing allotments that overlap the $i$ th HMA in 2006. The expected sign for this coefficient is positive because the more grazing allotments that overlap an HMA, the more livestock producers who will have the incentive to pressure the local BLM office to keep wild horses and burros under control and the higher the probability that a gather will be conducted. ${ }^{13}$ In our empirical analysis below, we examine the significance of alternative functional forms for both Excess Animals and Overlap Number.

The impact of increased membership in the Sierra Club on the BLM's gather decision is ambiguous. Environmental groups may side with wild horse and burro advocacy groups in trying to maintain and increase populations on the range, in which case an increase in Sierra Club membership would lead to a decrease in the likelihood (and size) of a gather. Alternatively, they may focus on conserving the public range or maintaining wildlife populations. If so, then an increase in membership (and presumptive associated lobbying efforts) would lead to an increase in the likelihood (and size) of a gather.

The variable Lawsuits is a binary variable equal to one if there was a judgment issued on a suit intended to halt the removal of wild horses and burros from HMA $i$ during year $t$ and zero otherwise. The judgment itself is not considered, because an injunction prevents any proposed gather while the suit is pending. We use this variable as an observable measure of lobbying efforts and consider alternative definitions, which we discuss below. If these lawsuits are effective in disrupting the BLM's management practices, the sign of the estimated coefficient is predicted to be negative, indicating that lawsuits lower the probability of a gather. Our empirical specifications also include the lagged value of the Lawsuit variable to account for possible delayed impacts of the legal actions. Insofar as a lawsuit filed by a wild horse advocacy group effectively delays or reduces the size of a gather, the BLM may compensate by conducting a gather with a higher likelihood following the resolution of the lawsuit.

Summary statistics for the variables used in this analysis are presented in table 1. Our final estimation data set is a balanced five-year panel of 195 HMAs. Notable insights from table 1 include the observation that about $22 \%$ of our observations have gathers, implying that there is an average

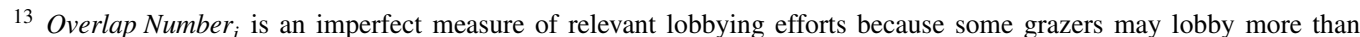
others and political influence may vary among grazers. Without additional information about these factors, however, we are unable to identify heterogeneous treatment effects. 
of slightly more than one gather per HMA in our time span. The maximum number of animals gathered is about 1,200, and the number of animals in excess of an HMA's AML peaks at about 800 . The maximum number of overlapping grazing permits for an HMA is sixty-two, but only nine of the HMAs in our data have more than twenty-five overlapping permits. Corresponding to the lawsuits described above, there are five observations in which the binary Lawsuit variable is assigned a value of one. Finally, the number of excess animals is fifty or fewer for almost $80 \%$ of our observations.

\section{Results}

The coefficient estimates from four specifications of a Probit model are reported in table 2 (results of comparable linear probability models are available on request). As expected, excess animals are an important determinant of gathers. This inference is consistent across functional forms. In column (1), which includes the logarithm of the number of excess animals, the marginal effect of a $10 \%$ increase in the number of excess animals is to increase the probability of a gather by $0.84 \%$, or 0.18 percentage points. ${ }^{14}$ In column (2) a quadratic specification provides a similar inference and indicates a peak probability of gather at about 436 excess animals, which is near the $99^{\text {th }}$ percentile in our data. Column (3) includes a categorical measure of the number of excess animals. The results indicate (1) a significantly higher probability of a gather when the number of excess animals is between 51 and 300 animals than in the omitted range from 0 to 50 animals and (2) a significantly higher probability of a gather when the number of excess animals exceeds 300 than when the excess is between 51 and 300. We find no statistical support for a difference between 0 and 1 to 50 excess animals.

Turning to the political economy factors, we find the number of overlapping grazing allotments is positively correlated with gathers but is statistically significant in only one of the three specifications with that variable. ${ }^{15}$ In column (3), we estimate that the marginal effect of a $10 \%$ increase in the number of overlapping allotments is to increase the probability of a gather by about one-half of $1 \%$, or about 0.11 percentage points.

Regarding the results related to the impacts of environmentalists, the estimated coefficient on our Sierra Club variable is negative and statistically significant in all specifications. This result is consistent with environmental groups having interests consistent with those of horse advocacy groups and also having sufficient political influence to affect the BLM's gather decisions. We also obtain negative and significant coefficient estimates if we substitute the absolute number of Sierra Club members in each state for the per capita measure. We readily acknowledge, however, that this variable may be a weak proxy for lobbying efforts and political influence specific to wild horses.

Finally, for the variable Lawsuit, the estimated coefficient is not statistically significant in any of the state fixed effect specifications, whereas the estimated coefficients on the Lagged Lawsuit variable are positive and statistically significant in all specifications. We find almost identical results when we change the coding of Lawsuit to reflect the period during which the suit was filed and pending. ${ }^{16}$ In the aftermath of a judgment, the probability of a gather increases, suggesting that management decisions cannot be delayed forever. The small number of observed lawsuits with judgments suggests that this is a weak measure of activities to reduce the number of wild horses gathers. Furthermore, it does not provide any insight into the strategy of filing a lawsuit with intent or option to settle.

\footnotetext{
14 We add 1 to the observed number of excess animals before taking the logarithm to account for HMAs with zero excess. All marginal effects discussed are calculated at the means of the explanatory variables.

15 We also examine alternative functional forms, including categorical variables for different numbers of overlapping allotments and interacted models that allow overlap to have a greater effect when more excess animals were present.

16 Results of these and additional specifications are available on request. Among these we included a lawsuit that affected twelve HMAs in Nevada, Utah, and Oregon, which was filed in 2001 but reached judgment in 2006. The inference does not differ from the results presented here. We also checked the sensitivity of the estimates to exclusion of the Wild Horse Advocate suit discussed above, which was filed late in 2006 and decided in early 2007. Again, we find no substantial differences in inference from these alternative specifications.
} 
Table 2. Gather Probits: Coefficient Estimates

\begin{tabular}{|c|c|c|c|c|}
\hline & (1) & (2) & (3) & (4) \\
\hline Log Excess Animals & $\begin{array}{l}0.364^{* * *} \\
(0.032)\end{array}$ & & & $\begin{array}{l}0.675^{* * *} \\
(0.112)\end{array}$ \\
\hline 100 Excess Animals & & $\begin{array}{l}1.004^{* * *} \\
(0.173)\end{array}$ & & \\
\hline 100 Excess Animals Squared & & $\begin{array}{c}-0.115^{* * *} \\
(0.031)\end{array}$ & & \\
\hline 51-150 Excess Animals & & & $\begin{array}{l}0.489^{* * *} \\
(0.100)\end{array}$ & \\
\hline 151-300 Excess Animals & & & $\begin{array}{l}0.437^{* *} \\
(0.178)\end{array}$ & \\
\hline 301+ Excess Animals & & & $\begin{array}{l}0.745^{* * *} \\
(0.120)\end{array}$ & \\
\hline Log Overlapping Allotments & $\begin{array}{c}0.007 \\
(0.114)\end{array}$ & $\begin{array}{c}0.057 \\
(0.108)\end{array}$ & $\begin{array}{c}0.177^{*} \\
(0.102)\end{array}$ & \\
\hline Sierra Club Membership & $\begin{array}{c}-0.472^{* *} \\
(0.225)\end{array}$ & $\begin{array}{c}-0.546^{* *} \\
(0.276)\end{array}$ & $\begin{array}{r}-0.418^{*} \\
(0.247)\end{array}$ & $\begin{array}{r}-0.489^{*} \\
(0.259)\end{array}$ \\
\hline Lawsuit & $\begin{array}{c}0.289 \\
(0.239)\end{array}$ & $\begin{array}{c}0.301 \\
(0.238)\end{array}$ & $\begin{array}{c}0.297 \\
(0.234)\end{array}$ & $\begin{array}{l}1.859^{* *} \\
(0.750)\end{array}$ \\
\hline Lag Lawsuit & $\begin{array}{l}1.313^{* * *} \\
(0.439)\end{array}$ & $\begin{array}{l}1.480^{* * *} \\
(0.495)\end{array}$ & $\begin{array}{l}1.991^{* * *} \\
(0.421)\end{array}$ & $\begin{array}{l}3.300^{* * *} \\
(0.956)\end{array}$ \\
\hline Constant & $\begin{array}{c}-0.951 \\
(0.604)\end{array}$ & $\begin{array}{c}-0.336 \\
(0.686)\end{array}$ & $\begin{array}{c}-0.411 \\
(0.618)\end{array}$ & $\begin{array}{c}-4.283^{* * *} \\
(0.689)\end{array}$ \\
\hline Fixed Effects & & & & \\
\hline State & $\mathrm{Y}$ & $\mathrm{Y}$ & $\mathrm{Y}$ & $\mathrm{N}$ \\
\hline Year & $\mathrm{Y}$ & $\mathrm{Y}$ & $\mathrm{Y}$ & $\mathrm{Y}$ \\
\hline HMA & $\mathrm{N}$ & $\mathrm{N}$ & $\mathrm{N}$ & $\mathrm{Y}$ \\
\hline Cluster & Year & Year & Year & Year \\
\hline Observations & 975 & 975 & 975 & 730 \\
\hline Pseudo $R^{2}$ & 0.266 & 0.202 & 0.080 & 0.402 \\
\hline
\end{tabular}

Notes: The dependent variable is a binary indicator of gather on an HMA in a given year. In column (4), we drop forty-nine HMAs for which a gather is not observed between 2004 and 2008. Cluster robust standard errors are in parentheses; year clustering provides the most

conservative inference as compared to state or HMA clusters. Single, double, and triple asterisks $(*, * *, * *)$ indicate statistical significance at the $10 \%, 5 \%$, and $1 \%$ level.

Column (4) of table 2 displays estimated coefficients from a model with HMA and year fixed effects. Because the value of Overlap Number is constant for all years within each HMA, we drop that variable from this specification. Our estimates remain relatively stable when compared to the similar specification in column (1).

Turning to the issue of the extent of gathers, table 3 displays the results from our analysis of Tobit specifications of equation (2). We use the Tobit specification to account for the censoring attendant with not gathering each HMA every year. The results support this choice, as evidenced by the significant censoring parameter $(\sigma)$ in all specifications. As with our probability of gather analysis, we again find that the number of animals in excess of the AML strongly determines how many animals are removed from the range. This is true across a range of functional specifications including logged and level measures. The estimated coefficient on the Excess Animals variable in column (1) suggests that a $10 \%$ increase in the number of excess animals results in an $18 \%$ increase in the number of animals removed. In column (2) the coefficients suggest that an increase of 100 excess animals results in removal of more than 100 animals over almost the entire range of 
this variable. Moreover, on average the number of animals gathered exceeds the number of excess animals by about sixty and the difference between these values is positive for more than $80 \%$ of the gathers conducted by the BLM. These observations suggest that when the BLM conducts gathers, the number of animals removed typically exceeds the excess above the AML. This allows the remaining herd to expand over a period of years before another costly gather must be undertaken. ${ }^{17}$

The Tobit specification provides support for the notion that the number of overlapping grazing allotments increases the number of animals removed when gathers are conducted. This correlation could be spurious if larger HMAs with more animals are more likely to overlap a greater number of allotments. The simple correlations between the number of overlaps and the acres in the HMA and the total population of wild horses and burros are not, however, particularly high -0.34 and 0.20 . Moreover, we also estimate specifications that interact categorical measures of the number of overlaps with the number of excess animals and find support for the idea that more livestock grazers and more excess horses lead to larger removals. Interestingly, this channel for political influence is positive, but-beyond an impact when the overlapping allotments increases from zero to a small number (one to four) - the impact does not increase with more grazers (results available on request). These findings contrast with similar specifications for the probability of a gather where support for analogous impacts of the number of overlapping allotments is weaker.

Another contrast to the probability of gather results is that Sierra Club membership shows no statistically significant impact, except in the HMA fixed effect specification. Consistent with table 2, the Lagged Lawsuit variable indicates that one year after a lawsuit judgment, a larger number of animals is gathered.

Collectively, the results in this section confirm the importance of the ecological AML rule in the BLM's management decisions that determines the supply of animals available to potential purchasers, whose decisions we examine next. Because we have no information on the costs of individual gathers, we have little to say about the economic merit of the BLM's gather schedule. ${ }^{18}$ We do, however, find evidence that plausible political factors affect both the probability of conducting a gather in any given HMA-year and the number of animals removed from the range.

\section{Adoption Analysis}

The ecological and political factors affecting the management of wild horse and burro herds affect both the stock of animals on the range and the flow of horses into holding facilities. Because the transfer options for these animals are limited by statute, the only way out of those facilities is through the Adopt-a-Horse program and the sales alternatives available to the BLM since 2004. In the event an animal is not placed with a private owner, the BLM leases pasture for long-term holding facilities to accommodate the animal for the term of its natural life. Examining the demand for the gathered horses and burros is a natural complement to the supply-side issues examined above.

\section{Data and Empirical Strategy}

Data on over 200,000 wild horses captured between 1985 and 2010 were obtained from the BLM's Information System. ${ }^{19}$ Each gathered animal has a unique individual identification number referred to as a freezemark because of the BLM practice of freeze-branding identification information on the necks of gathered horses. The data contain the date and herd management area of capture for

\footnotetext{
17 The estimated coefficients for the categorical variables in column (3) also suggest that the number of animals removed increases with the number of excess animals, although the variable definitions make the coefficient estimates less amenable to the interpretation above.

18 The average cost per animal for removal has decreased from \$515 in 1991 to \$390 in 2004 (all values in 2004 dollars). See U.S. Department of Interior, Bureau of Land Management (2004).

19 These data include all horses in the program before the end of June 2010. Our analysis does not include observations from the internet auctions that have been used in recent years to sell wild horses. See Adenkule et al. (2014) and Li (2010) for analyses of that transfer mechanism.
} 
Table 3. Removal Tobits: Coefficient Estimates

\begin{tabular}{|c|c|c|c|c|}
\hline & (1) & (2) & (3) & (4) \\
\hline \multirow[t]{2}{*}{ Log Excess Animals } & $1.785^{* * *}$ & & & $2.241^{* * *}$ \\
\hline & $(0.109)$ & & & $(0.008)$ \\
\hline \multirow[t]{2}{*}{100 Excess Animals } & & $1.923^{* * *}$ & & \\
\hline & & $(0.146)$ & & \\
\hline \multirow[t]{2}{*}{100 Excess Animals Squared } & & $-0.002^{* * *}$ & & \\
\hline & & $(0.001)$ & & \\
\hline \multirow[t]{2}{*}{ 51-150 Excess Animals } & & & $152.136^{* * *}$ & \\
\hline & & & $(38.983)$ & \\
\hline \multirow[t]{2}{*}{ 151-300 Excess Animals } & & & $160.337^{* * *}$ & \\
\hline & & & $(54.876)$ & \\
\hline \multirow[t]{2}{*}{ 301+ Excess Animals } & & & $426.569^{* * *}$ & \\
\hline & & & $(129.764)$ & \\
\hline \multirow[t]{2}{*}{ Log Overlapping Allotments } & 0.333 & & & \\
\hline & $(0.426)$ & & & \\
\hline \multirow[t]{2}{*}{ Overlapping Allotments } & & $5.678^{*}$ & $11.578^{* * *}$ & \\
\hline & & $(3.223)$ & $(4.413)$ & \\
\hline \multirow[t]{2}{*}{ Overlapping Allotments Squared } & & -0.049 & $-0.130^{*}$ & \\
\hline & & $(0.055)$ & $(0.075)$ & \\
\hline \multirow[t]{2}{*}{ Sierra Club Membership } & -1.361 & -31.958 & -48.393 & $-1.087^{* * *}$ \\
\hline & $(2.010)$ & $(85.483)$ & $(106.598)$ & $(0.008)$ \\
\hline \multirow[t]{2}{*}{ Lawsuit } & 0.804 & 29.092 & 23.484 & $3.902^{* * *}$ \\
\hline & $(2.682)$ & $(112.087)$ & $(132.060)$ & $(0.253)$ \\
\hline \multirow[t]{2}{*}{ Lag Lawsuit } & $4.770^{* * *}$ & $295.153^{* *}$ & $540.040^{* * *}$ & $8.190^{* * *}$ \\
\hline & $(1.611)$ & $(136.654)$ & $(92.400)$ & $(0.191)$ \\
\hline \multirow[t]{2}{*}{ Constant } & -6.755 & -260.454 & -275.155 & $-23.016^{* * *}$ \\
\hline & $(4.151)$ & $(175.543)$ & $(220.409)$ & $(0.017)$ \\
\hline \multirow[t]{2}{*}{$\sigma$} & $4.829^{* * *}$ & $229.992^{* * *}$ & $324.332^{* * *}$ & $3.775^{* * *}$ \\
\hline & $(0.191)$ & $(19.867)$ & $(25.182)$ & $(0.005)$ \\
\hline \multicolumn{5}{|l|}{ Fixed Effects } \\
\hline State & $\mathrm{Y}$ & $\mathrm{Y}$ & $\mathrm{Y}$ & $\mathrm{N}$ \\
\hline Year & $\mathrm{Y}$ & $\mathrm{Y}$ & $\mathrm{Y}$ & $\mathrm{Y}$ \\
\hline HMA & $\mathrm{N}$ & $\mathrm{N}$ & $\mathrm{N}$ & $\mathrm{Y}$ \\
\hline Observations & 975 & 975 & 975 & 975 \\
\hline Pseudo $R^{2}$ & 0.148 & 0.084 & 0.024 & 0.260 \\
\hline
\end{tabular}

Notes: In columns (1) and (4), the dependent variable is the logarithm of the number of animals removed by gather on an HMA in a given year. In columns (2) and (3), the dependent variable is the number of hundred animals removed by gather on an HMA in a given year. Sandwich robust standard errors are in parentheses. Single, double, and triple asterisks $(*, * *, * *)$ indicate statistical significance at the $10 \%$, $5 \%$, and $1 \%$ level.

each individual animal as well as information on a series of phenotypical characteristics. We restrict this portion of our analysis to the adoption and sale of horses, in part because the market for wild burros appears to be distinct from the market for horses. For each horse that is eventually adopted or sold, we obtain information on the date of transfer, whether training was received, the age at time of transfer, and the price paid.

Since 1997, the Adopt-a-Horse program has relied almost exclusively on auctions to allocate horses. To avoid a confound between competitive and noncompetitive bidding procedures, we omit 
the adoption data prior to $1997 .{ }^{20}$ Table 4 displays summary statistics on the whole data set (since 1985), as well as on the trimmed sample we analyze below. Historically, the BLM has been very successful in finding homes for gathered horses, with almost $70 \%$ being adopted or sold over the course of the full sample. Despite the addition of several new sale options in 2004, transfers relative to the total number captured has fallen to less than $60 \%$ in our trimmed sample. An important consequence of this decline is that more horses are being managed on long-term pasture by the BLM, thereby increasing the program's costs.

Of the wild horses in the trimmed sample, 52\% are mares, $29 \%$ are geldings, and $19 \%$ are stallions. The mean age of these animals is about four years, but the relatively large standard deviation of 5.25 years illustrates that managers choose to remove horses of various ages. The average age of the animals adopted between 1997 and 2010 is 2.5 years with a standard deviation of roughly the same value. The animals that were sold are much older on average (slightly more than 13 years), and the standard deviation of the age of these horses is large. About $8 \%$ of the wild horses adopted or sold are trained (either halter or saddle). The average fee paid for animals adopted by private parties since 1997 is \$170 with a standard deviation of \$228 (in 2009 dollars). Nearly 6\% of the horses transferred in the trimmed sample were dispersed under the 2004 sale authority, at an average real price of $\$ 17$ per head.

The upper portion of table 5 provides a glimpse of the phenotypical appearance of horses. One potentially attractive feature of wild horses is the wide variety in colors. Although $62 \%$ of the horses are either brown (Bay or Brown in table 5) or red (Sorrel or Chesnut), the remaining 38\% are distributed across a broad range of alternatives, which is a testament to the genetic variety of wild horses. The highest proportions transferred are for pintos and palominos. The bottom portion of table 5 suggests that there is considerable variation across states in the fraction of captured horses that are adopted or sold. Whereas the state with by far the largest number of horses captured, adopted, or sold is Nevada, that state also has the lowest proportion of horses transferred to private hands.

The probability of adoption for wild horses is estimated based on physical characteristics using an empirical model of the following form:

$$
\text { Adopted }_{i}=\Phi\left(\text { Age at Capture }_{i}, \text { Sex }_{i}, \text { Color }_{i}, \text { Markings }_{i}, \text { Slaughter Ban }_{i}\right)+\varepsilon_{i} .
$$

The dependent variable is a binary variable equal to one if the horse was adopted or sold and zero otherwise. The variable Age at Capture corresponds to the age in the year of its capture. Younger horses are expected to have a higher probability of adoption.

The model also includes a number of physical characteristics of wild horses that are typically used to estimate hedonic models for horse sales. These characteristics include sex (mare, stallion, or gelding), color, whether one or more legs have white markings (Any White Feet), the presence of white markings in the face (Any Blaze), and the number of face whorls (Face Whorls). Face whorls are thought to be an indicator of a horse's trainability (Górecka et al., 2007), so are expected to have a positive influence on adoption. No definitive predictions can be made for the signs of the estimated coefficients of the other variables.

The sample used to estimate the probability of adoption or sale of a wild horse consists of 114,882 observations on wild horses captured between 1997 and 2010. The base groups in the regressions are mare for sex and brown or bay for color. When fixed effects are added to the model, the base groups are Nevada for state and 1997 for year of capture. We also include the binary variable Slaughter Ban, which we assign a value of one for observations from 2007 and after (when the recent ban on horse slaughter in U.S. facilities was in effect), and a value of zero in earlier years. Insofar as-despite the efforts of the BLM described above-some wild horses were being slaughtered for

20 This might raise the concern that only unadopted horses are included in the estimating sample for years 1985-1996. This is not the case-a total of 3,063 horses captured during that span were adopted or sold after 1996. The total number of horses gathered during the years 1997-2010 was 116,369. Of these, the only horses excluded from our analysis are the small proportion that were transferred through mechanisms other than adoption in competitive auctions and the sale options available since 2004 . 
Table 4. Sample Summary Statistics for Horses

\begin{tabular}{|c|c|c|}
\hline & $\begin{array}{c}\text { Full Sample } \\
1985-2010\end{array}$ & $\begin{array}{c}\text { Trimmed Sample } \\
1997-2010\end{array}$ \\
\hline Total Records & 203,095 & 114,882 \\
\hline Adopted & 136,008 & 60,181 \\
\hline Sold & 3,839 & 3,802 \\
\hline Total Transferred & 139,716 & 63,983 \\
\hline \multicolumn{3}{|l|}{ Age in Years } \\
\hline \multirow[t]{2}{*}{ At Capture } & 3.97 & 4.14 \\
\hline & $(4.79)$ & $(5.25)$ \\
\hline \multirow[t]{2}{*}{ At Adoption } & 3.28 & 2.49 \\
\hline & $(3.23)$ & $(2.22)$ \\
\hline \multirow[t]{2}{*}{ At Sale } & 13.22 & 13.18 \\
\hline & $(5.30)$ & $(5.30)$ \\
\hline \multicolumn{3}{|l|}{ Sex Variables } \\
\hline Mare & 106,165 & 59,151 \\
\hline Gelding & 40,137 & 33,645 \\
\hline Stallion & 56,792 & 22,086 \\
\hline \multicolumn{3}{|l|}{ Training } \\
\hline Trained & 5,904 & 4,847 \\
\hline \multicolumn{3}{|l|}{ Nominal Prices } \\
\hline \multirow[t]{2}{*}{ Adopted } & 111.76 & 144.56 \\
\hline & (140.99) & (196.05) \\
\hline \multirow[t]{2}{*}{ Sold } & 16.38 & 16.24 \\
\hline & (39.69) & (39.53) \\
\hline \multicolumn{3}{|c|}{ Real Prices (\$ 2009) } \\
\hline \multirow[t]{2}{*}{ Adopted } & 148.53 & 169.57 \\
\hline & $(167.45)$ & $(227.72)$ \\
\hline \multirow[t]{2}{*}{ Sold } & 17.52 & 17.32 \\
\hline & $(43.52)$ & $(43.35)$ \\
\hline
\end{tabular}

Notes: The trimmed sample includes horses adopted in 1997 and later, even if those horses were gathered in earlier years. Sold horses are those transferred using one of the options available since 2004. BLM records indicate that a total of 4,134 head were sold, though we exclude 295 observations with missing data. A total of 131 horses in the trimmed sample were adopted, returned, and then sold. Those horses are recorded as sold above. The first column reports only complete records from the raw data and therefore excludes a total of 29,071 incomplete or inconsistent observations on horses. All 29,020 observations pertaining to burros are also excluded. The age and price variables represent means, with standard deviations in parentheses.

human consumption in U.S. plants, the imposition of the slaughter ban would eliminate that source of demand. In this case, we expect both the probability of adoption and the auction or sale price for the horses to fall when the slaughter ban goes into effect. Both transfer prices and the probability of adoption could also fall if the slaughter ban directly impacted only private horse markets, but there is some substitutability between private and wild horses. If slaughter for human consumption is not an important demand determinant, or if there is little or no substitutability between private and wild horses, then we expect the coefficient on this variable to be zero.

Hedonic models have been used in a number of studies to estimate the implicit value of physical and genetic attributes of breeding and racing horses in auctions (Chezum and Wimmer, 1997; Vickner and Koch, 2001; Neibergs, 2001; Taylor et al., 2006; Maynard and Stoeppel, 2007; Lange 
Table 5. Summary Statistics for Trimmed Sample

\begin{tabular}{|c|c|c|c|c|}
\hline Variable & Captured & Adopted & Sold & $\begin{array}{l}\text { Proportion } \\
\text { Transferred }\end{array}$ \\
\hline \multicolumn{5}{|l|}{ Color Variables } \\
\hline Bay or Brown & 46,418 & 22,753 & 1,696 & 0.53 \\
\hline White or Gray & 8,799 & 4,372 & 255 & 0.53 \\
\hline Sorrel or Chestnut & 24,891 & 12,972 & 764 & 0.55 \\
\hline Dun, Buckskin, or Grulla & 9,499 & 5,937 & 263 & 0.65 \\
\hline Roan & 6,972 & 4,134 & 207 & 0.62 \\
\hline Black & 10,807 & 5,189 & 426 & 0.52 \\
\hline Pinto & 3,874 & 2,584 & 101 & 0.69 \\
\hline Palomino & 2,376 & 1,572 & 47 & 0.68 \\
\hline Appaloosa & 956 & 532 & 36 & 0.59 \\
\hline Other & 290 & 147 & 7 & 0.53 \\
\hline Total & 114,882 & 60,286 & 3,802 & 0.56 \\
\hline \multicolumn{5}{|l|}{ State of Capture } \\
\hline Arizona & 125 & 88 & 6 & 0.75 \\
\hline California & 10,869 & 6,078 & 287 & 0.58 \\
\hline Colorado & 2,820 & 1,807 & 64 & 0.66 \\
\hline Idaho & 1,932 & 1,234 & 62 & 0.67 \\
\hline Montana & 178 & 172 & 5 & 0.99 \\
\hline New Mexico & 4,122 & 3,617 & 62 & 0.89 \\
\hline Nevada & 58,152 & 27,510 & 2,173 & 0.51 \\
\hline Oregon & 9,300 & 5,422 & 214 & 0.60 \\
\hline Utah & 8,098 & 4,049 & 326 & 0.54 \\
\hline Wyoming & 19,286 & 10,309 & 603 & 0.57 \\
\hline Total & 114,882 & 60,286 & 3,802 & 0.56 \\
\hline
\end{tabular}

Notes: See notes in table 4 for construction of the trimmed sample.

et al., 2010; Taylor and Sieverkropp, 2013). These models provide estimates of the impact of physical characteristics as well as performance, pedigree, and health information on the market value of these horses. There are some similarities between these private horse auctions and the wild horse adoptions, specifically the emphasis by the BLM on phenotypic descriptions of animals to potential adopters.

The sample used to estimate the hedonic pricing model consists of 63,983 observations on the fees paid for wild horses adopted or sold between 1997 and 2010. The model to be estimated takes the form:

$$
\text { Fee Paid }_{i}=f\left(\operatorname { P r } \left(\text { Adopted }_{i}, \text { Trained }_{i}, \text { Sold }_{i}, \text { Adoption Age }_{i}, \text { Sex }_{i},\right.\right.
$$

$$
\text { Color } \left._{i}, \text { Markings }_{i} \text {, Slaughter Ban } i\right)+\eta_{i} \text {. }
$$

The dependent variable Fee Paid $i$ corresponds to the real price an adopter or buyer paid for a wild horse. The consumer price index with a base year of 2009 is used to convert nominal prices to real. Because some horses are not transferred, the presence of the well-known selection problem is addressed by using a Heckit-type model. Selection bias concerns arise because the information on fees paid by adopters and buyers is only available for those wild horses that were adopted or sold. The inverse Mills' ratio is included in the hedonic pricing model to account for the probability that a given animal could be adopted. We obtain values for this variable using the estimates obtained from the Probit adoption model that we discuss below.

The variable Age at Transfer is the age at which an animal was adopted or sold. This variable can be different from the Age at Capture variable used in the probability of adoption regressions, 
though it is highly correlated. The estimated coefficient on this variable is expected to be negative, indicating that people are willing to pay a lower price for older horses because they are generally more difficult to manage and train. To allow for nonlinear age effects, we also include a quadratic term.

The variable Trained is binary, equal to one if the horse is trained and zero otherwise. The fee for trained horses in our data represents the difference between the actual fee paid by the buyer and the training costs paid by the BLM. Training makes a wild horse more docile, increasing its potential for riding and therefore its value. A positive sign for this variable would indicate that the BLM is able to sell trained horses for more than the sum of (1) the fee the BLM pays for training and (2) the average fee in the full sample of animals transferred. Every trained horse we observe in our data is transferred to a private owner. The regressor Sold is a binary variable whose value is set equal to one if the wild horse was sold under the sale authority of the BLM and zero otherwise. The minimum acceptable sale price is $\$ 1$. Moreover, the animals available for sale are ten years of age or older or are wild horses that have been offered for adoption three times without success. Accordingly, we expect a negative estimated coefficient for this variable.

The model also includes a number of physical characteristics of wild horses that are typically used to estimate hedonic models for horse sales, which we also use to estimate the probability of adoption or sale. One notable addition to the second-stage equation is the binary variable Visible Defect, which indicates whether the animal has a record of injury. The expected impact of such information is to lower the revenue received by the BLM. The binary Slaughter Ban variable discussed above is also included.

\section{Results}

In table 6 we report Probit coefficient estimates of equation (3) for four fixed effects specifications. Our expectation that younger horses are more desirable is borne out by the estimated coefficient on Age at Capture, which implies that the marginal effect of a one-year increase in age at capture decreases the probability of adoption by about 4 percentage points, all else equal.

The estimated coefficients on the sex variables are both statistically different from zero and indicate that (ceteris paribus) stallions are more likely to be adopted than mares, while geldings are less likely to be adopted. The estimated coefficients imply that stallions are 14.1 to 20.5 percentage points more likely to be adopted than mares, while geldings have an 11.7 to 13.1 percentage point lower probability of being adopted than mares. In the early 2000s, the BLM started castrating virtually all stallions. The change in BLM policy regarding gelding stallions is reflected both in the raw data and in the smaller stallion marginal effects when year controls are included.

The coefficients on the color variables are uniformly positive and statistically significant, suggesting that all other colors are more likely to be adopted or sold than bay or brown horses. Most of these phenotypical variables are of limited interest, although they do provide insights into the underlying demand for wild horses. The estimates for the probability of transfer are important both for estimation of equation (4) and for consideration of the broader fiscal implications of program modifications discussed below.

The results of the second-stage regressions on adoption and sale fees are displayed in table 7 . The estimated coefficient on the inverse Mills' ratio is significant at the 0.01 level, indicating that transferred horses are different from those in the care of the BLM and validating the choice of empirical strategy. The effect of Age at Transfer changes when year fixed effects are included. When year fixed effects are not included in the model (columns 1 and 2), the age increases the fee paid up to about six years of age, after which the fee paid decreases with age. When year fixed effects are included, there is no clear statistical relationship between transfer fees and age.

Wild horses that have been sold since 2004 received around \$100 less than horses that were adopted in competitive auctions. The estimate on Trained is positive and significant, suggesting that 
Table 6. Adoption Probits: Coefficient Estimates $(n=114,882)$

\begin{tabular}{|c|c|c|c|c|}
\hline & (1) & (2) & (3) & (4) \\
\hline \multirow[t]{2}{*}{ Age at Capture } & $-0.111^{* * *}$ & $-0.108^{* * *}$ & $-0.102^{* * *}$ & $-0.097^{* * *}$ \\
\hline & $(0.001)$ & $(0.001)$ & $(0.001)$ & $(0.001)$ \\
\hline \multirow[t]{2}{*}{ Face Whorls } & $0.103^{* * *}$ & $0.080^{* * *}$ & $0.135^{* * *}$ & $0.104^{* * *}$ \\
\hline & $(0.023)$ & $(0.023)$ & $(0.026)$ & $(0.026)$ \\
\hline \multirow[t]{2}{*}{ Any Blaze } & $0.036^{* * *}$ & $0.035^{* * *}$ & $0.040^{* * *}$ & $0.039^{* * *}$ \\
\hline & $(0.010)$ & $(0.010)$ & $(0.011)$ & $(0.011)$ \\
\hline \multirow[t]{2}{*}{ Any White Feet } & 0.010 & 0.011 & $0.019^{* *}$ & $0.020^{* *}$ \\
\hline & $(0.009)$ & $(0.009)$ & $(0.009)$ & $(0.009)$ \\
\hline \multirow[t]{2}{*}{ Stallion } & $0.547^{* * *}$ & $0.531^{* * *}$ & $0.413^{* * *}$ & $0.373^{* * *}$ \\
\hline & $(0.012)$ & $(0.012)$ & $(0.013)$ & $(0.013)$ \\
\hline \multirow[t]{2}{*}{ Gelding } & $-0.333^{* * *}$ & $-0.322^{* * *}$ & $-0.319^{* * *}$ & $-0.298^{* * *}$ \\
\hline & $(0.009)$ & $(0.009)$ & $(0.010)$ & $(0.010)$ \\
\hline \multirow[t]{2}{*}{ White or Gray } & $0.118^{* * *}$ & $0.085^{* * *}$ & $0.145^{* * *}$ & $0.087^{* * *}$ \\
\hline & $(0.016)$ & $(0.016)$ & $(0.017)$ & $(0.018)$ \\
\hline \multirow[t]{2}{*}{ Sorrel or Chestnut } & $0.037^{* * *}$ & $0.034^{* * *}$ & $0.055^{* * *}$ & $0.053^{\text {*** }}$ \\
\hline & $(0.011)$ & $(0.011)$ & $(0.012)$ & $(0.012)$ \\
\hline \multirow[t]{2}{*}{ Dun, Buckskin, or Grulla } & $0.301^{* * *}$ & $0.301^{* * *}$ & $0.391^{* * *}$ & $0.396^{* * *}$ \\
\hline & $(0.016)$ & $(0.016)$ & $(0.017)$ & $(0.017)$ \\
\hline \multirow[t]{2}{*}{ Roan } & $0.222^{* * *}$ & $0.217^{* * *}$ & $0.219^{* * *}$ & $0.209^{\text {*** }}$ \\
\hline & $(0.018)$ & $(0.018)$ & $(0.019)$ & $(0.019)$ \\
\hline \multirow[t]{2}{*}{ Black } & $0.042^{* * *}$ & $0.051^{* * *}$ & $0.057^{* * *}$ & $0.073^{* * *}$ \\
\hline & $(0.015)$ & $(0.015)$ & $(0.016)$ & $(0.016)$ \\
\hline \multirow[t]{2}{*}{ Pinto } & $0.393^{* * *}$ & $0.362^{* * *}$ & $0.571^{* * *}$ & $0.515^{\text {*** }}$ \\
\hline & $(0.024)$ & $(0.024)$ & $(0.027)$ & $(0.028)$ \\
\hline \multirow[t]{2}{*}{ Palomino } & $0.377^{* * *}$ & $0.368^{* * *}$ & $0.471^{* * *}$ & $0.461^{* * *}$ \\
\hline & $(0.029)$ & $(0.029)$ & $(0.033)$ & $(0.033)$ \\
\hline \multirow[t]{2}{*}{ Appaloosa } & $0.329^{* * *}$ & $0.302^{* * *}$ & $0.422^{* * *}$ & $0.366^{\text {*** }}$ \\
\hline & $(0.046)$ & $(0.046)$ & $(0.051)$ & $(0.052)$ \\
\hline \multirow[t]{2}{*}{ Slaughter Ban } & $-0.281^{* * *}$ & $-0.295^{* * *}$ & $2.986^{* * *}$ & $3.053^{* * *}$ \\
\hline & $(0.010)$ & $(0.010)$ & $(0.081)$ & $(0.084)$ \\
\hline \multirow[t]{2}{*}{ Constant } & $0.439^{* * *}$ & $0.397^{* * *}$ & $1.283^{* * *}$ & $1.238^{* * *}$ \\
\hline & $(0.027)$ & $(0.027)$ & $(0.037)$ & $(0.037)$ \\
\hline \multicolumn{5}{|l|}{ Fixed Effects } \\
\hline State & $\mathrm{N}$ & $\mathrm{Y}$ & $\mathrm{N}$ & $\mathrm{Y}$ \\
\hline Year & $\mathrm{N}$ & $\mathrm{N}$ & $\mathrm{Y}$ & $\mathrm{Y}$ \\
\hline Pseudo $R^{2}$ & 0.185 & 0.191 & 0.322 & 0.336 \\
\hline
\end{tabular}

Notes: The dependent variable is a binary indicator of whether an animal is adopted or sold during the observed period. Omitted sex is mare and omitted color is brown or bay. Sandwich robust standard errors are in parentheses. Single, double, and triple asterisks (*, **, ***) indicate statistical significance at the $10 \%, 5 \%$, and $1 \%$ level.

horses with training garnered about $\$ 120$ more than the training costs paid by the BLM plus the average fee paid for other adopted horses without training.

The estimates on the sex variables are generally positive and statistically significant, suggesting that both stallions and geldings are transferred for higher prices than mares. In the final two columns, which include year fixed effects, the policy change regarding gelding of stallions is reflected in that most stallions were sold in earlier years when prices were higher. Controlling for these time factors 
Table 7. Adoption Fees: Heckit Coefficient Estimates $(n=63,983)$

\begin{tabular}{|c|c|c|c|c|}
\hline & (1) & $(2)$ & (3) & (4) \\
\hline \multirow[t]{2}{*}{ Inverse Mills Ratio } & $-2.049^{* * *}$ & $-2.491^{* * *}$ & $1.314^{* *}$ & $2.365^{* * *}$ \\
\hline & $(0.556)$ & $(0.628)$ & $(0.534)$ & $(0.602)$ \\
\hline \multirow[t]{2}{*}{ Age at Transfer } & $1.971^{* * *}$ & $1.763^{* * *}$ & 0.226 & -0.158 \\
\hline & $(0.544)$ & $(0.551)$ & $(0.581)$ & $(0.588)$ \\
\hline \multirow[t]{2}{*}{ Age Squared } & $-0.165^{* * *}$ & $-0.151^{* * *}$ & $-0.064^{* *}$ & -0.041 \\
\hline & $(0.024)$ & $(0.024)$ & $(0.026)$ & $(0.026)$ \\
\hline \multirow[t]{2}{*}{ Sold } & $-108.167^{* * *}$ & $-105.568^{* * *}$ & $-99.807^{* * *}$ & $-93.681^{* * *}$ \\
\hline & $(2.839)$ & $(2.766)$ & $(3.158)$ & (3.115) \\
\hline \multirow[t]{2}{*}{ Trained } & $122.122^{* * *}$ & $124.940^{* * *}$ & $121.770^{* * *}$ & $124.463^{* * *}$ \\
\hline & $(5.261)$ & $(5.348)$ & $(5.261)$ & $(5.344)$ \\
\hline \multirow[t]{2}{*}{ Stallion } & $4.980^{* *}$ & $5.404^{* * *}$ & 2.273 & 2.346 \\
\hline & $(2.062)$ & $(2.024)$ & $(2.087)$ & $(2.053)$ \\
\hline \multirow[t]{2}{*}{ Gelding } & $9.555^{* * *}$ & $8.199^{* * *}$ & $10.044^{* * *}$ & $9.355^{* * *}$ \\
\hline & $(2.043)$ & $(2.152)$ & $(2.025)$ & $(2.105)$ \\
\hline \multirow[t]{2}{*}{ Visible Defect } & $-32.906^{* * *}$ & $-25.907^{* * *}$ & $-32.507^{* * *}$ & $-22.632^{* * *}$ \\
\hline & $(6.406)$ & $(6.501)$ & $(6.440)$ & $(6.569)$ \\
\hline \multirow[t]{2}{*}{ Any White Feet } & -0.151 & 1.418 & -1.429 & 0.280 \\
\hline & $(1.724)$ & $(1.675)$ & $(1.746)$ & $(1.695)$ \\
\hline \multirow[t]{2}{*}{ Face Whorls } & $123.444^{* * *}$ & $118.389^{* * *}$ & $100.791^{* * *}$ & $96.633^{* * *}$ \\
\hline & $(2.928)$ & $(2.849)$ & $(2.771)$ & $(2.696)$ \\
\hline \multirow[t]{2}{*}{ Any Blaze } & $11.951^{* * *}$ & $12.407^{* * *}$ & $8.923^{* * *}$ & $9.491^{* * *}$ \\
\hline & $(2.381)$ & $(2.335)$ & $(2.435)$ & $(2.387)$ \\
\hline \multirow[t]{2}{*}{ White or Gray } & $33.152^{* * *}$ & $32.150^{* * *}$ & $30.094^{* * *}$ & $28.498^{* * *}$ \\
\hline & $(2.781)$ & $(2.869)$ & $(2.754)$ & $(2.834)$ \\
\hline \multirow[t]{2}{*}{ Sorrel or Chestnut } & $11.560^{* * *}$ & $12.019^{* * *}$ & $10.224^{* * *}$ & $10.585^{* * *}$ \\
\hline & $(1.602)$ & $(1.610)$ & $(1.570)$ & $(1.580)$ \\
\hline \multirow[t]{2}{*}{ Dun, Buckskin, or Grulla } & $105.070^{* * *}$ & $99.280^{* * *}$ & $103.452^{* * *}$ & $98.996^{* * *}$ \\
\hline & $(6.449)$ & $(6.025)$ & $(6.367)$ & $(6.011)$ \\
\hline \multirow[t]{2}{*}{ Roan } & $38.291^{* * *}$ & $36.689^{* * *}$ & $37.160^{* * *}$ & $35.586^{* * *}$ \\
\hline & $(2.607)$ & $(2.566)$ & $(2.592)$ & $(2.553)$ \\
\hline \multirow[t]{2}{*}{ Black } & $25.895^{* * *}$ & $22.119^{* * *}$ & $23.328^{* * *}$ & $19.659^{* * *}$ \\
\hline & $(2.388)$ & $(2.403)$ & $(2.366)$ & $(2.386)$ \\
\hline \multirow[t]{2}{*}{ Pinto } & $60.181^{* * *}$ & $56.401^{* * *}$ & $65.457^{* * *}$ & $62.485^{* * *}$ \\
\hline & $(4.237)$ & $(4.234)$ & $(4.250)$ & $(4.228)$ \\
\hline \multirow[t]{2}{*}{ Palomino } & $47.401^{* * *}$ & $46.999^{* * *}$ & $47.381^{* * *}$ & $47.727^{* * *}$ \\
\hline & $(4.241)$ & $(4.225)$ & $(4.285)$ & $(4.262)$ \\
\hline \multirow[t]{2}{*}{ Appaloosa } & $34.714^{* * *}$ & $29.546^{* * *}$ & $31.652^{* * *}$ & $27.290^{* * *}$ \\
\hline & $(7.118)$ & $(7.232)$ & $(7.209)$ & $(7.340)$ \\
\hline \multirow[t]{2}{*}{ Cremello } & $42.569^{* * *}$ & $48.874^{* * *}$ & $39.501^{* * *}$ & $47.441^{* * *}$ \\
\hline & $(14.929)$ & $(14.836)$ & $(14.393)$ & $(14.344)$ \\
\hline \multirow[t]{2}{*}{ Slaughter Ban } & $-55.294^{* * *}$ & $-57.445^{* * *}$ & $-21.314^{* * *}$ & $-15.506^{* * *}$ \\
\hline & $(2.495)$ & $(2.462)$ & $(4.108)$ & $(4.175)$ \\
\hline \multicolumn{5}{|l|}{ Fixed Effects } \\
\hline State & $\mathrm{N}$ & Y & $\mathrm{N}$ & $\mathrm{Y}$ \\
\hline Year & $\mathrm{N}$ & $\mathrm{N}$ & $\mathrm{Y}$ & $\mathrm{Y}$ \\
\hline$R^{2}$ & 0.375 & 0.381 & 0.382 & 0.389 \\
\hline
\end{tabular}

Notes: Dependent variable is real fee (in \$2009) received for animal. Estimates control for the probability that a given animal is adopted or sold (Inverse Mills Ratio), which we calculate from the estimated Probit coefficients in column 4 of table 6. Omitted sex is mare and omitted color is brown or bay. Cluster robust standard errors in parentheses. Single, double, and triple asterisks $(*, * *, * * *)$ indicate statistical significance at the $10 \%, 5 \%$, and $1 \%$ level.

reveals no statistical preference for stallions relative to mares. The observation that both mares and stallions sell for less than geldings suggests that the breeding value to potential buyers of gathered females and stallions is low. The estimated coefficients for the color variables are all positive and statistically different from zero, implying that brown-bay horses sell for less than other colors, with 
grullas and duns bringing the highest premium. There are significant price differences across states, reflecting the different genetic pools of horses across HMAs (fixed effects estimates are available on request).

\section{Policy Considerations}

Our analysis provides insights into the supply and demand for wild horses. From an economic perspective, the essence of the management problems encountered with the WH\&B program is that the quantity of wild horses supplied at the minimum price of $\$ 125$ in the Adopt-a-Horse program is greater than the quantity of horses demanded. There are three fundamental approaches that might be employed to reduce this surplus: (1) increase the demand for wild horses, (2) decrease the supply of horses the BLM has available for adoption or sale, and (3) decrease the minimum acceptable transfer fee. We demonstrate that a relatively straightforward modification of the current WH\&B program has the potential to substantially reduce its costs. We also discuss the implications of our analysis for the relationship between the 2007 slaughter ban on horses and the market for BLM wild horses.

\section{Increasing Demand}

One approach available to the BLM to increase the demand for wild horses is to increase the number that are trained. In our empirical analysis above, we find that the average fee for trained horses exceeds the sum of the amount paid by the BLM to contract for the training and the average fee paid for untrained horses by about $\$ 120$. Moreover, all of the trained horses in our data were adopted. From these observations, we infer that training horses prior to offering them for adoption is an effective way to increase the demand for the BLM's wild horses. The BLM is currently involved in several horse-training programs-including high-profile efforts like the Extreme Mustang Makeover, sponsored in partnership with the Mustang Heritage Foundation. Several western state penitentiaries have arrangements for inmates to train horses. Since 2007, the BLM has dramatically increased the number of trained horses offered for adoption. Assuming training can be expanded at costs similar to those currently incurred by the BLM, our results suggest this may be a good use of taxpayer money, though lack of comprehensive cost data precludes more extensive analysis.

Another approach to increasing the demand for wild horses would be to relax restrictions on commercial use, including slaughter. Because these restrictions were ingrained in the original wild horse legislation, the political prospects may be dim. Nonetheless, relaxing these stipulations is an option that could reduce the surplus of wild horses and associated fiscal costs.

\section{Decreasing Supply}

Our analysis suggests that the BLM adheres to AMLs as a decision rule. The internal calculations of BLM managers may or may not reflect societal preferences for balancing wild horses, livestock, and wildlife (Huffaker, Wilen, and Gardner, 1990). The degree to which AMLs account for these considerations is not clear. It is possible that AMLs could be adjusted to moderate the supply of potentially adoptable animals, but we have no evidence that BLM adjusts targets in this way.

A primary objective of wild horse advocacy groups is to maintain or increase the number of free-roaming wild horses and burros in the American West. Our results indicate that lawsuits filed by these groups to prevent gathers are not effective in doing so. It could be that the purpose of these lawsuits is to affect how as opposed to whether to gather horses. We cannot reject that hypothesis. If, however, lawsuits are the main weapon of mustang advocates, the results we present above suggest that they are a weak one, although they do raise the profile of wild horses in the public consciousness. Livestock grazers, on the other hand, are concerned about adequate livestock feed on BLM grazing 
allotments rather than with the number of free-roaming horses and burros. Our results suggest that, consistent with these interests, excess animals are removed.

One possible way to reconcile these two competing interests would be to allow wild horse advocates to purchase grazing permits from livestock producers who currently hold them. This would allow wild horses to effectively replace some of the livestock on BLM lands. Implementing this option would involve fundamental changes in the structure and provisions of federal grazing leases and would require the resolution of myriad complex issues.

Possibly the most important of these issues is related to the fecundity of wild horses. Suppose the provisions of grazing permits were altered to allow transfers with the end result of an additional ten horses on an HMA. Because wild horses lack significant natural predators, horse populations grow at a rate of $20 \%$ per year (National Research Council, 2013), and the additional ten horses would expand to 380 within twenty years. There is a short-run decrease in supply of adoptable animals as the free-roaming populations expand, but in the long run the supply is greater. This highlights the inevitability of competing demands for the range, whether between wild horses and domestic livestock or between wild horses and native wildlife. Removing domestic livestock may simplify, but will not alleviate, the optimal renewable resource problem.

Decreasing the fecundity of wild horses and burros is an option to reduce the BLM's supply of wild horses for adoption or sale. Since 1978, the BLM has sought to develop a safe, effective, reversible, and humane fertility control agent. The immunocontraceptive agent PZP, which meets most of these requirements and has been used since 1992, has shown an initial effectiveness of $90 \%$ in preventing pregnancies in mares. Cost considerations associated with the fact that annual booster shots are required motivated the development of an experimental twenty-two-month PZP vaccine, which has been used in field trials since January 2000. Garrott and Oli (2013) endorsed broader use of PZP to help curtail wild horse fecundity, suggesting that the birth rate could be cut in half. The authors estimate savings of $\$ 16,110$ in saved long-term holding costs by preventing each additional birth, which are slightly higher than our more conservative estimates.

\section{Decreasing the Minimum Transfer Fee}

Potentially the most cost-effective way to reduce the current surplus of horses is to alter the WH\&B program by decreasing the minimum transfer fee. ${ }^{21}$ The BLM currently allows horses to be adopted or sold for less than $\$ 125$ under a number of circumstances. ${ }^{22}$ These efforts reduce the surplus but have not come close to eliminating it. We consider two alternative price-reduction schemes and estimate the budgetary implications of each. To estimate the response to lower minimum fees, we use the estimated coefficients from our fee regression in column (4) of table 7. For each horse in our trimmed sample that was not transferred, we predict two values, one through the adoption mechanism $($ Sold $=0)$ and one via the sale authority $($ Sold $=1)$. Because none of the horses was adopted or sold, the value for the Age at Transfer variable is missing. The mean duration between capture and transfer is 335 days, so we add one year to the Age at Capture value as our measure of the age at transfer when generating predicted prices.

Table 8 shows the estimated impact of progressively lower adoption fees. From table 4, there are 50,899 $(=114,882-63,983)$ horses in our trimmed sample that were not yet adopted or sold. The mean predicted adoption fee for these horses is $\$ 126$ with a range from $\$ 519$ to $-\$ 6$, where the latter value indicates the BLM would have to pay a prospective buyer $\$ 6$ to adopt the horse.

21 Because the $\$ 125$ minimum adoption fee was established by legislation, the BLM likely does not have the authority to simply change it; further legislative action would be required. We also note that some non-price barriers, such as preventing wild horses from being sold for slaughter or other commercial purposes, are also mandated in the WH\&B Act.

${ }^{22}$ For example, the sales options available to the BLM since 2004 have provided an outlet for transferring lower-valued wild horses into private hands for less than $\$ 125$. The BLM also has experimented with a pilot program in New Mexico that essentially offers $\$ 500$ to adopters of untrained wild horses four years of age and older. See Elizondo (2011) for additional information on this program (p. 109), as well as other circumstances under which horses can be adopted for less than $\$ 125$ (p. 21). 
Table 8. Impact of Lowering Minimum Adoption Fee

\begin{tabular}{|c|c|c|c|c|c|c|}
\hline \multirow[b]{2}{*}{ Fee } & \multicolumn{3}{|c|}{ Full Sample $(n=50,899)$} & \multicolumn{3}{|c|}{ Excluding 2009-10 $(n=42,509)$} \\
\hline & Number & Lower C.I. & Upper C.I. & Number & Lower C.I. & Upper C.I. \\
\hline$\$ 75$ & 43,366 & 40,392 & 45,797 & 39,879 & 37,625 & 41,239 \\
\hline$\$ 25$ & 50,735 & 50,235 & 50,867 & 42,504 & 42,457 & 42,508 \\
\hline$\$ 0$ & 50,896 & 50,863 & 50,899 & 42,509 & 42,508 & 42,509 \\
\hline$-\$ 6$ & 50,899 & 50,877 & 50,899 & 42,509 & 42,508 & 42,509 \\
\hline Fee & $\begin{array}{c}\text { Numb } \\
\text { Transfe }\end{array}$ & & $\begin{array}{c}\text { Revenue } \\
(\$)\end{array}$ & $\begin{array}{r}\text { Foregone LT } \\
\text { (million }\end{array}$ & Cost & $\begin{array}{l}\text { Net Savings } \\
\text { (millions) }\end{array}$ \\
\hline$\$ 75$ & 43,36 & & 968,891 & $\$ 377$ & & $\$ 383$ \\
\hline$\$ 25$ & 50,73 & & $, 391,332$ & $\$ 445$ & & $\$ 451$ \\
\hline$\$ 0$ & 50,89 & & $, 394,216$ & $\$ 445$ & & $\$ 452$ \\
\hline$-\$ 6$ & 50,89 & & $, 394,208$ & $\$ 445$ & & $\$ 452$ \\
\hline
\end{tabular}

Notes: All monetary values expressed in \$2009. Calculations are based on figures in left panel above, from the specification in column (4) of table 7. Predicted adoption revenues sum individual predicted values rather than assuming uniform prices. Long-term holding (LTH) costs are estimated at a present value of $\$ 475$ per year over an average expected lifetime of twenty-five years. A fifteen-year-old horse therefore has an expected long-term holding cost of $\$ 4,750$.

The mean predicted fee for the horses that were actually adopted is $\$ 166$, which is very close to the observed sample mean of $\$ 170$. The number of horses adopted at each of several alternative minimum adoption fees are shown in the top panel. This exercise suggests that all of the 50,899 horses would have been adopted with a minimum fee of $-\$ 6$.

In the right panel of table 8, we exclude horses captured in 2009 and 2010 to avoid any potential bias associated with including horses yet to move through the BLM adoption process. Many of the more recently gathered animals have good prospects for being adopted, particularly if trained; our estimates suggest that although $18 \%$ would be adopted under current adoption rules without training, nearly all would attract bids of $\$ 125$ with training. In each panel we construct a $95 \%$ confidence interval on the number of animals transferred at each of the fee thresholds.

To follow up on our earlier results regarding the value of training, we also predict adoption fees for all 50,899 horses that are not transferred had they been trained. All but three head have predicted values above the current $\$ 125$ minimum. This provides support for our earlier suggestion that training additional horses is one potential remedy for the current surplus of horses. These calculations do not account for possible changes in the costs of training. Such a large influx of horses into the horse training market could well change marginal costs of training as well as returns in the adoption market. Current initiatives such as the Extreme Mustang Makeover are efforts to entice horse trainers who might otherwise avoid wild horses to help improve the prospects for otherwise unadoptable horses.

In the lower panel of table 8, we report the estimated budgetary impacts of reducing the minimum adoption fee below its current level of $\$ 125$. There are two sources of savings. One is revenue from adoption fees, where we calculate this revenue for each horse using the predicted values from our regressions as counterfactual fees rather than assuming a uniform adoption prices (for example, 43,366 at a uniform $\$ 75$ per head would yield $\$ 3,252,450$, not $\$ 5,968,891$ ). The second source of 
Table 9. Impact of Lowering Minimum Sale Fee

\begin{tabular}{|c|c|c|c|c|c|c|}
\hline \multirow[b]{2}{*}{ Fee } & \multicolumn{3}{|c|}{ Full Sample $(n=50,899)$} & \multicolumn{3}{|c|}{ Excluding 2009-10 $(n=42,509)$} \\
\hline & Number & Lower C.I. & Upper C.I. & Number & Lower C.I. & Upper C.I. \\
\hline$-\$ 25$ & 44,957 & 42,402 & 47,137 & 40,900 & 39,238 & 41,845 \\
\hline$-\$ 75$ & 50,816 & 50,550 & 50,855 & 42,508 & 42,485 & 42,509 \\
\hline$-\$ 100$ & 50,899 & 50,890 & 50,899 & 42,509 & 42,509 & 42,509 \\
\hline Fee & \multicolumn{2}{|c|}{$\begin{array}{c}\text { Number } \\
\text { Transferred }\end{array}$} & $\begin{array}{c}\text { Revenue } \\
(\$)\end{array}$ & \multicolumn{2}{|c|}{$\begin{array}{c}\text { Foregone LTH Cost } \\
\text { (millions) }\end{array}$} & $\begin{array}{l}\text { Jet Savings } \\
\text { (millions) }\end{array}$ \\
\hline$-\$ 25$ & \multicolumn{2}{|c|}{44,957} & $1,871,687$ & \multicolumn{2}{|l|}{$\$ 393$} & $\$ 395$ \\
\hline$-\$ 75$ & \multicolumn{2}{|c|}{50,816} & $1,632,715$ & \multicolumn{2}{|l|}{$\$ 445$} & $\$ 446$ \\
\hline$-\$ 100$ & \multicolumn{2}{|c|}{50,899} & $1,626,051$ & \multicolumn{2}{|l|}{$\$ 445$} & $\$ 446$ \\
\hline
\end{tabular}

Notes: All monetary values expressed in \$2009. Calculations are based on figures in left panel above, from the specification in column (4) of table 7. Predicted sale revenues sum individual predicted values rather than assuming uniform prices. Because some predicted sale prices are positive, sums are positive despite reported thresholds being strictly non-positive. Long-term holding (LTH) costs are estimated at a present value of $\$ 475$ per year over an average expected lifetime of twenty-five years. A fifteen-year-old horse therefore has an expected long-term holding cost of $\$ 4,750$.

savings is foregone costs of long-term holding. ${ }^{23}$ For each alternative minimum fee in table 8 , over $98 \%$ of the net savings from reduced adoption fees is from lower maintenance costs. Training would provide an even greater fillip, considering that our estimated average price effect is about $\$ 125$ per head, although the additional adoption revenue of around $\$ 6.3$ million is small relative to the avoided maintenance costs. Even if expanding training programs comes at higher marginal cost, the budgetary effects could still be positive by avoiding the large long-term holding costs.

In table 9 we perform a similar exercise in which we contemplate reliance on the sale mechanism to reduce the surplus of horses. This lowers the mean predicted transfer fee to $\$ 32$ while lowering the range from $\$ 425$ to $-\$ 100$. The effective minimum payment under the sales provisions currently available to the BLM is $\$ 1-$ a price not low enough to attract buyers for all horses offered by the BLM. In the top left panel the number of horses sold at several minimum prices below $\$ 1$ are shown. Based on our predicted values, all of the horses would have been sold if the minimum fee had been lowered to $-\$ 100$. In the right panel we again exclude the horses gathered in 2009 and 2010.

The lower panel of table 9 displays our estimates of the budgetary impact of different minimum sales fees. As is the case with the altered adoption program considered in table 8, most of the budgetary savings are from reduced maintenance costs. Because we report the sum of the individual predicted values, the net budgetary impact is positive, although the additional revenues are smaller than for adoptions with a comparable number of horses transferred. As the minimum acceptable sales fee drops further, implying the BLM pays buyers more to take possession of wild horses, the additional sales revenue falls. With the adoption results in table 8 , almost all of the horses are transferred when the minimum fee is reduced to $\$ 25$, and the budgetary impacts are small for further reductions. Similarly, table 9 indicates that reductions in the minimum sale fee below $-\$ 75$ to transfer the last few horses have small impacts. Comparing a modified adoption regime with a modified sale regime suggests that the savings are comparable because of the dominance of foregone long-term holding costs.

\footnotetext{
${ }^{23}$ For these calculations, we assume that for each horse that is not transferred, the present value of long-term pasture cost borne by taxpayers would have been $\$ 475$ per year. Actual costs depend on the elasticity of supply of pasture for long-term holding of wild horses. We use the capture age of each animal to calculate expected maintenance costs, assuming all animals live to age twenty-five.
} 


\section{Horse Slaughter Ban}

The WH\&B Act traces its origins to widely publicized concern about the humanity of gathering wild horses expressly for slaughter. Recent policy debate about the domestic slaughter of horses for human consumption has been equally emotional. Since 2007, federal funds for required inspectors have not been available for domestic facilities slaughtering horses for human consumption. Widespread concern within the horse industry has focused on whether this policy change has had a negative effect on horse prices. Taylor and Sieverkropp (2013) examined the effect of the slaughter ban on one regional market, finding that prices decreased $12-16 \%$ for most horses. Because most wild horses are adopted at prices well below domestic horse prices, the linkages between these markets may be weak. Accordingly, rather than apply the Taylor and Sieverkropp estimates, we use our econometric results to measure the effects of the domestic slaughter ban on the wild horse market.

As mentioned above, the imposition of the slaughter ban might have affected wild horse markets through two channels. First, if-despite the various non-price barriers employed by the BLMsome wild horses were illegally being purchased for slaughter for human consumption, then the ban would reduce demand from that group of buyers and prices would fall. Second, if there is some substitutability between low-valued private horses and wild horses, then-even if no wild horses were going to slaughter buyers-decreased prices for private horses from the slaughter ban would cause a decrease in demand for wild horses and a reduction in their adoption or sale price. If either of these channels apply, the slaughter ban will also result in a reduction in the probability that wild horses are transferred to private owners, thus increasing the long-term holding costs associated with excess horses.

We gain insights into the possible impacts of the slaughter ban on the market for wild horses from the estimated coefficients on the binary Slaughter Ban variable in tables 6 and 7. Focusing on column (4), the coefficients measure the average impact of the ban on adoption probabilities and prices received for wild horses. The year fixed effects capture year-to-year variation, including possible impacts of the recession following 2007 on the wild horse market. In table 7, the estimated coefficient on Slaughter Ban is negative and statistically significant; the magnitude is about $\$ 15$, which is comparable in percentage terms to Taylor and Sieverkropp (2013).

The estimated coefficient on the Slaughter Ban variable in table 6 is positive and significant, which seems counterintuitive. We explain this result as follows. Because all trained horses in our data are adopted, the Trained variable cannot be included in the adoption regressions. An examination of our data reveals that, whereas the average number of trained horses offered annually by the BLM from 1997 to 2006 was 238, the average number in the years 2007-2009 was 710. This would result in an increase in the probability of adoption that we cannot control for in our regressions in table 6 . If the slaughter ban did decrease the probability of adoption, this effect is outweighed by the offsetting effect of the concurrent increase in the number of trained horses offered by the BLM.

Our conclusion from these results is that prices in the market for wild horses appear to have fallen during the years 2007-2010 as a result of the slaughter ban, along with prices in other segments of the equine market. This is part of a longer reduction in the probability of adoption or sale and gradually declining prices.

\section{Conclusions}

Wild horses and burros are an important part of the cultural legacy of the western United States. Since 2000, the BLM's management of these animals has become increasingly costly. Our objective analysis of the political factors that affect both the removal of horses and burros from the range and the hedonics of the placement programs contributes to an understanding of the economics of the wild horse and burro program. Our empirical results suggest that an increase in the number of affected livestock grazers leads to more animals being removed when gathers occur. We are unable 
to account for heterogeneous treatment effects stemming from particular political connections of specific grazers but suggest this could be a fruitful direction for future research. Lawsuits filed by wild horse advocacy groups delay but do not prevent removal of horses from the range.

Wild horses are a heterogeneous lot, and our adoption analysis confirms that although some horses are valuable, many more have little market value. Current minimum adoption fees act as a price floor and reduce the number of horses adopted. Because providing life-long care for the resulting surplus of wild horses is the primary source of increasing program costs, we identify relaxing the price support as one possible means of containing these costs. Our analysis suggests the BLM's training programs increase the probability that animals are placed in private hands, thereby showing potential for reducing the surplus and its attendant costs. Improved contraceptives have the potential to reduce the number of horses offered by the BLM, whereas reducing livestock numbers on BLM-managed range with offsetting increases in wild horses likely would exacerbate current problems in the long-run. It seems likely, however, that neither expanded training programs nor improved contraceptives alone will reduce the surplus of BLM wild horses or contain the WH\&B program's escalating costs.

We demonstrate that lowering the minimum transfer fee would increase horse placements into adoptive homes, while also lowering the pasturage bill for horses in long-term holding. The potential budgetary savings are substantial. We estimate savings of about $\$ 450$ million over the past twentyfive years if a market-clearing adoption fee had been specified. It is important to note that the BLM has moved in this direction with, for example, the sale program it implemented in 2004. An advantage of the decreased minimum adoption fees we analyze over the 2004 options is that lower fees would avoid potential controversy and suspicions when, as one example, a BLM agent negotiates with a single buyer for the sale of thirty-six wild horses at $\$ 10$ each. We also assess the impact of closure of domestic equine slaughter facilities for human consumption and find evidence that prices for wild horses fell along with those for other classes of horses.

BLM officials gather and remove horses subject to ecological constraints such as sex ratios, so non-marginal adjustments to the naturally-occurring distribution of animals are unlikely. At the margin, however, officials may be able to adjust gather and adoption management to balance longterm tradeoffs in exchange for short-term benefits or costs. This is another potential direction for future work.

A clear-eyed assessment of the causes of recent trends in the WH\&B program has the potential to lead to policy changes that result in sustainable costs and to ensure that the well-being of these iconic free-roaming wild horses and burros remains paramount in the interests of public land managers and potential adopters.

[Received October 2014; final revision received September 2015.] 


\section{References}

"America's Mustangs: Put Out to Pasture." The Economist (2011). Available online at http://www.economist.com/node/21530154. doi: 10.1162/rest.1997.79.3.521.

Adenkule, O., S. Saghian, C. Stowe, and L. Markus. "A Hedonic Price Analysis of Internet Auctions for the BLM's Wild Horses and Burros." 2014. Annual Meeting of the Southern Agricultural Economics Association, February 1-4, Dallas, TX. Available online at http://purl.umn.edu/162469.

Bartholow, J. "Economic Benefit of Fertility Control in Wild Horse Populations." Journal of Wildlife Management 71(2007):2811-2819. doi: 10.2193/2007-064.

Bastian, C. T., L. W. van Tassell, A. C. Cotton, and M. A. Smith. "The Opportunity Costs of Wild Horses: An Allotment Case Study in Wyoming." 1997. Annual Meeting of the Western Agricultural Economics Association, July 13-16, Reno/Sparks, NV. Available online at http://purl.umn.edu/35953.

Buckley, A. W., and W. R. Buckley. "The Appropriate Degree of Management under the Wild Free-Roaming Horses and Burros Act." California Western Law Review 19(1982):419.

_. "Straying Wild Horses and the Range Landowner: The Search for Peaceful Coexistence." Public Land Law Review 4(1983):29.

Chezum, B., and B. Wimmer. "Roses or Lemons: Adverse Selection in the Market for Thoroughbred Yearlings." Review of Economics and Statistics 79(1997):521-526.

Elizondo, V. An Economic and Political Analysis of the Wild Horse and Burro Program. M.S. Thesis, Montana State University, Bozeman, MT, 2011.

Garrott, R. A., and M. K. Oli. "A Critical Crossroad for BLM's Wild Horse Program." Science 341(2013):847-848. doi: 10.1126/science.1240280.

General Accountability Office. "Bureau of Land Management: Effective Long-Term Options Needed to Manage Unadoptable Wild Horses." Tech. Rep. GAO, 09-77, GAO, Washington, DC, 2008. Available online at http://www.gao.gov/ new.items/d0977.pdf.

Górecka, A., M. Golonka, M. Chruszczewski, and T. Jezierski. "A Note on Behaviour and Heart Rate in Horses Differing in Facial Hair Whorl." Applied Animal Behaviour Science 105(2007):244248. doi: 10.1016/j.applanim.2006.05.013.

Gross, J. E. "A Dynamic Simulation Model for Evaluating Effects of Removal and Contraception on Genetic Variation and Demography of Pryor Mountain Wild Horses." Biological Conservation 96(2000):319-330. doi: 10.1016/S0006-3207(00)00078-1.

Hansen, R. M., R. C. Clark, and W. Lawhorn. "Foods of Wild Horses, Deer, and Cattle in the Douglas Mountain Area, Colorado.” Journal of Range Management 30(1977):116-118.

Hobbs, N. T., D. C. Bowden, and D. L. Baker. "Effects of Fertility Control on Populations of Ungulates: General, Stage-Structured Models." Journal of Wildlife Management 64(2000):473491. doi: $10.2307 / 3803245$.

Hubbard, R. E., and R. M. Hansen. "Diets of Wild Horses, Cattle, and Mule Deer in the Piceance Basin, Colorado.” Journal of Range Management 29(1976):389-392.

Huffaker, R. G., J. E. Wilen, and B. D. Gardner. "A Bioeconomic Livestock/Wild Horse TradeOff Mechanism for Conserving Public Rangeland Vegetation." Western Journal of Agricultural Economics 15(1990):73-82.

Iraola, R. "The Wild Free-Roaming Horses and Burros Act of 1971." Environmental Law 35(2005):1049.

Krysl, L. J., M. E. Hubbert, B. F. Sowell, G. E. Plumb, T. K. Jewett, M. A. Smith, and J. W. Waggoner. "Horses and Cattle Grazing in the Wyoming Red Desert, I. Food Habits and Dietary Overlap." Journal of Range Management 37(1984):72-76. doi: 10.2307/3898828.

Lange, K., J. Johnson, K. Wilson, and W. Johnson. "Price Determinants of Ranch Horses Sold at Auction in Texas." 2010. Annual Meeting of the Southern Agricultural Economics Association, February 6-9, Orlando, FL. Available online at http://purl.umn.edu/56491. 
Li, Y. Essays in Regional Economics and Natural Resource Management. University of Nevada, Reno, 2010.

Maynard, L. J., and K. M. Stoeppel. "Hedonic Price Analysis of Thoroughbred Broodmares in Foal." Journal of Agribusiness 25(2007):181.

McInnis, M. L., and M. Vavra. "Dietary Relationships among Feral Horses, Cattle, and Pronghorn in Southeastern Oregon." Journal of Range Management 40(1987):60-66. doi: 10.2307/3899363.

McKnight, T. L. "The Feral Horse in Anglo-America." Geographical Review 49(1959):506-525. doi: $10.2307 / 212210$.

Miller, R. "Habitat Use of Feral Horses and Cattle in Wyoming's Red Desert." Journal of Range Management 36(1983):195-199.

National Research Council. Using Science to Improve the BLM Wild Horse and Burro Program: A Way Forward. National Academies Press, 2013.

Neibergs, J. S. "A Hedonic Price Analysis of Thoroughbred Broodmare Characteristics." Agribusiness 17(2001):299-314. doi: 10.1002/agr.1017.

Olsen, F. W., and R. M. Hansen. "Food Relations of Wild Free-Roaming Horses to Livestock and Big Game, Red Desert, Wyoming.” Journal of Range Management 30(1977):17-20.

Taylor, M., and E. Sieverkropp. "The Impacts of U.S. Horse Slaughter Plant Closures on a Western Regional Horse Market." Journal of Agricultural and Resource Economics 38(2013):48-63.

Taylor, M. R., K. C. Dhuyvetter, T. L. Kastens, M. Douthit, and T. L. Marsh. "Show Quality Quarter Horse Auctions: Price Determinants and Buy-Back Practices." Journal of Agricultural and Resource Economics 31(2006):595.

Thomas, H. S. The Wild Horse Controversy. A. S. Barnes and Co., Inc., 1979.

U.S. Department of Interior, Bureau of Land Management. "Adoption of Wild Horses and Burros.” BLM Handbook H-4750-2, U.S. Department of Interior, Bureau of Land Management, Washington, DC, 1998.

—. "Budget Justifications and Performance Information: Fiscal Year 2005." 2004. Available online at http://www.blm.gov/pgdata/etc/medialib/blm/wo/Business_and_Fiscal_Resources/ justification.Par.1963.File.dat/2005Justification.pdf.

- BLM Announces First Sale of Wild Horses under New Law, 2005. Available online at http://www.blm.gov/wo/st/en/info/newsroom/2005/march/NR0503_1.html.

—_ "Budget Justifications and Performance Information: Fiscal Year 2015." 2014a. Available online at http://www.doi.gov/budget/appropriations/2015/upload/FY2015_BLM_Greenbook.pdf.

—. "National Wild Horse \& Burro Advisory Board Meeting Minutes." 2014b. April 14-15, Sacramento, CA.

"BLM Seeks Bids for New Off-Range Pastures to Care for Wild Horses." 2015. Available online at http://www.blm.gov/wo/st/en/info/newsroom/2015/february/2_25_2015b.html.

National Instruction Memoranda, Various Years. Available online at http://www.blm.gov/wo/st/en/info/regulations/Instruction_Memos_and_Bulletins/national_ instruction.html.

Vickner, S. S., and S. I. Koch. "Hedonic Pricing, Information, and the Market for Thoroughbred Yearlings." Journal of Agribusiness 19(2001):173-190.

Wyman, W. D. The Wild Horse of the West. Lincoln, NE: University of Nebraska Press, 1945. 